\title{
Effects Of usage of Smart devices On Child Health and Behavior In Thi-Qar Governorate / Comparative Study ( 2018 - 2019 )
}

\author{
Amin Turki Atiyah / Assistant Professor, CABP \\ Adnan Mohsun Alrikabi / Assistant Professor, CABP \\ Mohammed A. Alatabi / DCH in Pediatrics
}

\begin{abstract}
:
The past decade has seen a profound increase in use of technology by children, some as young as one year of age. Critical milestones for child sensory, motor and attachment development are not being met. Developmental delay, obesity, mental illness, and attention deficit ,sleep disruption, and also Social disorders such as: communication, aggression and declining empathy , are now becoming the norm.

The aims: of this study are to determine if there is any significant statistical association between excessive usage of smart devices and change in child behavior and health ( either positive effect or negative effect). And to explore the purpose role of family about this problem .

Method: This is a comparative study done on population of children aged between 3-14 years who are living in Thi-qar Governorate, south of Iraq, during period from August, 2018 till April, 2019.

The study included 200 healthy children chosen selectively from the relatives of patients who consult outpatient departments of the hospitals and neighbors. One hundred of them are exposed to the risk factor (use smart devices) and considered as a cases and other 100 are not exposed to the risk factor and considered as control.
\end{abstract}

Results: The study shows that most of children who use the smart devices are from urban area ( $73 \%$ ) versus ( $27 \%$ ) are from rural area and $69 \%$ of them are using the devices less than 5 hours \ day and $31 \%$ of them are using it more than 5 hours $\backslash$ day.

Also the study shows there is a significant adverse effect of prolong use of digital devices by children on their vision , playing with others and the sleep patterns . Also it associated with significant increase in the percentage of headache and neck pain, but it is associated with increase in their learning abilities. Conclusions: Prolong using of smart devices have many adverse effects on child health and behaviors in the form of aggressive behavior, decrease in school performance, headache , neck pain, visual problems and appetite disturbances, but its usage might increase their learning abilities.

Recommendations: To encourage zero media usage for children under 2 years of age and limited time for those over 10 years of age and this problem need further studies to follow up the effect of digital devices on child health and behavior.

Key wards: Digital devices, child health, behavior. 
ISSN (Print):1992-92 18, ISSN (Online):1992-92 18

DOI: https://doi.org/10.32792/utq/utjmed/19/1/6

\section{INTRODUCTION :}

The past decade has seen a profound increase in use of technology by children, some as young as one year of age. Critical milestones for child sensory, motor and attachment development are not being met. Developmental delay, obesity, mental illness, and attention deficit ,sleep disruption, and also Social Disorders such as: communication, aggression and declining empathy ,are now becoming the norm $(1,2)$.

Media violence has now been categorized as a Public Health Risk due to causal links to child aggression (3). Brain development research shows technology overuse by children results in "pruning" of tracks to the frontal cortex, adversely affecting executive functioning and impulse control $(4,5)$. Schools continue to escalate use of "educational" technologies without any research evidence to show efficacy or safety.

It is now time for parents, teachers, health professionals, government, researchers and technology production corporations to join together to manage balance between healthy activity and technology use, a concept termed Balanced Technology Management (6).

As we become increasingly more reliant and absorbed in technology, it is no surprise that today's children have become avid users as well (7). Laptops are being developed for children as young as five. Smart phones are now in the hands of children as young as ten (8).

Sixty percent of jobs in the market are technology related, and children need the tech advantage to be successful in such an environment .
On the other hand, however, the children using technology are becoming socially stunted $(9,10)$.

Technology has opened up a world of great opportunities, but these opportunities have come with great risks. In order to fully understand the argument surrounding technology and children, we must understand the pros and the cons, and how our decisions about technology use will affect today's children as they develop $(11,12)$.

The objectives are :

-To determine if there is any significant statistical association between excessive usage of smart devices and change in child behavior and health ( either positive effect or negative effect).

- To explore the purpose role of family about this problem.

\section{Methodology:}

This is a comparative study done on population of children aged between 314 years who are living in Thi-qar Governorate, south of Iraq, during period from August, 2018 till April, 2019.

The study included 200 healthy children chosen selectively from the relatives of patients who consult outpatient departments of the hospitals and neighbors. One hundred of them are exposed to the risk factor (use smart devices) and considered as a cases and other 100 are not exposed to the risk factor and considered as control.

\section{Procedure :}

All the children who are participated in this study (both cases and control groups) was healthy, not complain 
ISSN (Print):1992-92 18, ISSN (Online):1992-92 18

DOI: https://doi.org/10.32792/utq/utjmed/19/1/6

from any somatic or psychiatric diseases, acute or chronic illnesses . After taking the consent verbally and by direct interviewing with children and their relatives, the information was taken from both groups about ( age, gender, family number, order of child in family, economic status and address). Also the family asked about the duration and period of using smart devices, then asked about the adverse effects ( such as : obesity, aggression, decrease school performance, headache, neck pain , and visual and learning problems ), then asked about family actions toward this situation .All questionnaires reported on the papers and then insert the data in the Excel sheets

Quality control : during data collection, has been emphasis on the accuracy of the children and their relatives response to the questions, and during the data processes, the information checked several times .

Statistical analysis: by using Excel sheet and SPSS program, version 25

Ethical consideration : consent was taken verbally.

\section{Results and Discussion}

The digital devices ( smart phones, laptops, I Paid ) are becoming increasingly popular among kids over Thi -Qar Governorate, but without any evaluation neither for its advantages nor for its disadvantages on their health or behavior .
Recent studies shows that prolong use of digital devices by children might be suffering from the side effects of over use. This includes digital eye strain ( red , dry or irritant, blurred vision, or fatigue ) (13), also associated with headache, back ,neck andlor shoulder pain. Excessive using of smart phones at early age can also trigger poor eye sight for kids(14) .

Also studies shows that child who spends more than four hours a day watching television or using digital devices is more likely to be over weight than one who watches less than two hours.

Studies shows an association of digital devices usage with sleep problems in pre - school - aged children.

The studies revealed that the length and timing (day versus evening time) of device usage, affected the amount of the increase in the sleep problems (15).

Also children who spend more time with media devices reportedly have lower levels of personal contentment and have tendency to get in trouble more often. They also report feeling more sad or bored than their counter parts ( 16 )

In this study, the researchers found that most of children who use the smart devices are from urban area ( $73 \%$ ) versus ( $27 \%$ ) are from rural area, (as shown in figure 1), and that may be due to the differences in the education levels and economic status. 
ISSN (Print):1992-92 18, ISSN (Online):1992-92 18

DOI: https://doi.org/10.32792/utq/utjmed/19/1/6

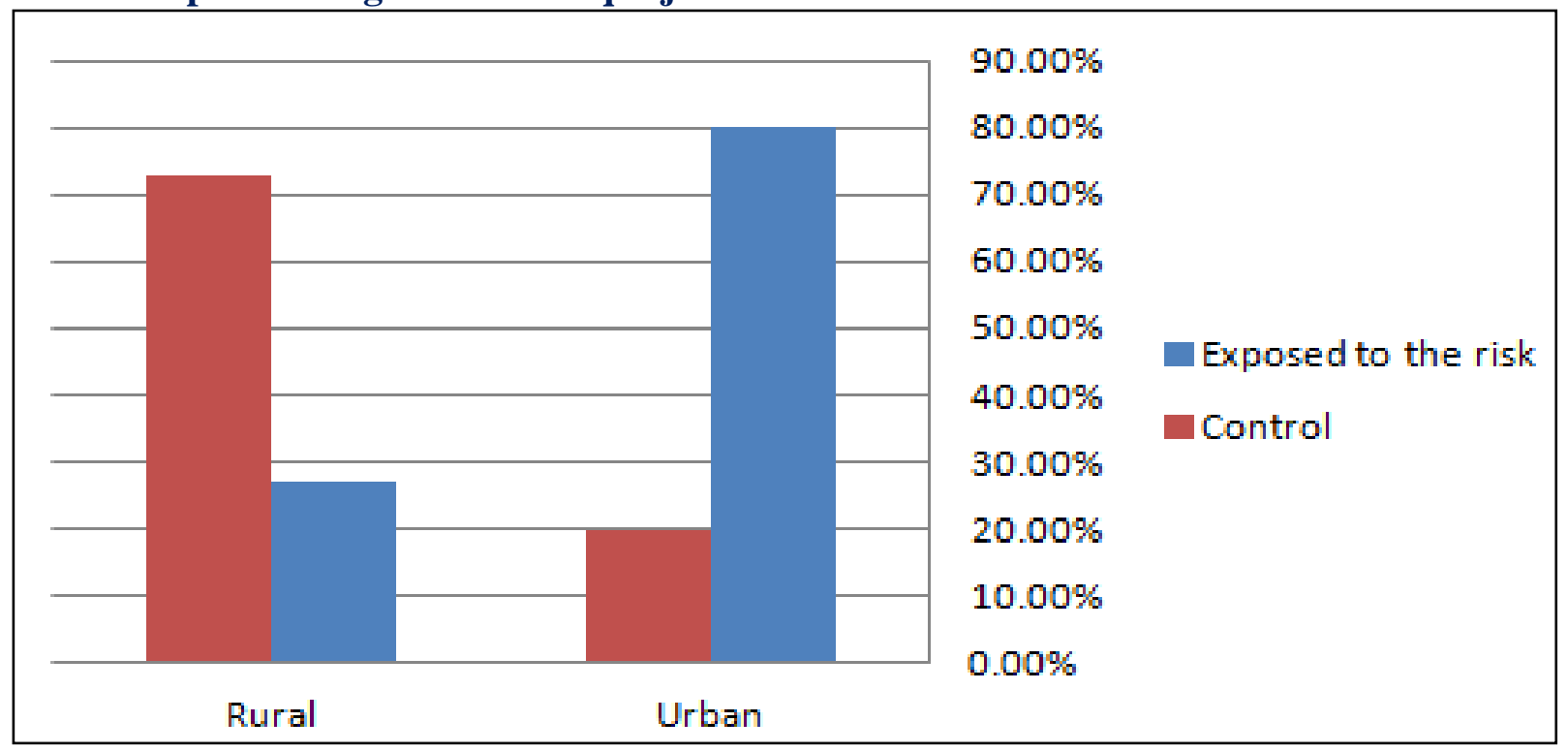

Figure 1:distribution of children exposed to the risk(users of digital devices) and control according to their residency

It have been found that $69 \%$ of them are using the devices less than 5 hours $\backslash$ day and $31 \%$ of them are using it more than 5 hours $\backslash$ day .

The study shows there is a significant adverse effect of prolong use of digital devices by children on their vision, playing with others and the sleep patterns . Also it associated with significant increase in the incidence of headache and neck pain, but it is associated with increase in their learning abilities (as shown in figures 2, 3, 4, 5,6 and 7).

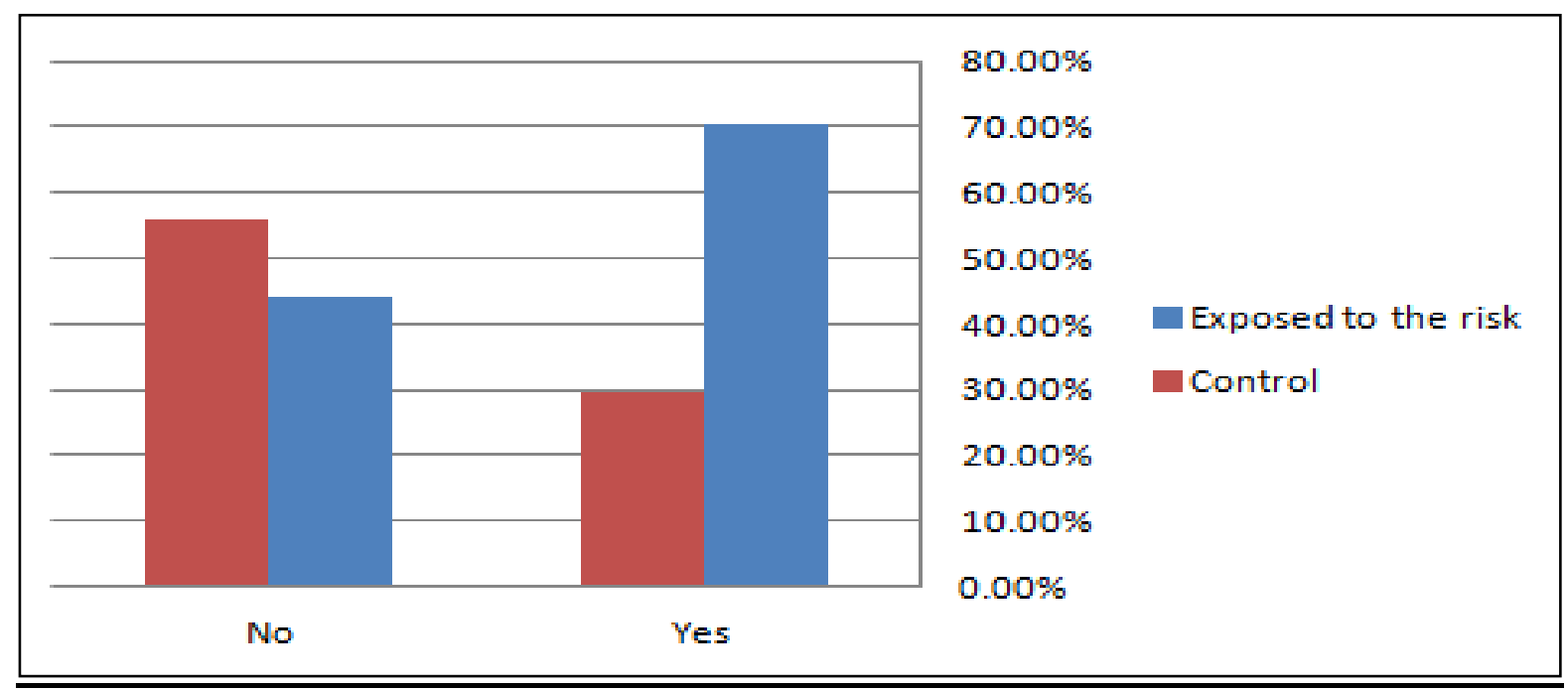

Figure 2:Percentage of neck pain among exposed to risk group(users of digital devices) and control group 
Thi-Qar Medical Journal (TQMJ):Vol.(19), No.(1), 2020

Web Site: $\underline{\text { https://jmed.utq.edu.iq }}$

Email:utjmed@utq.edu.iq

ISSN (Print):1992-92 18, ISSN (Online):1992-92 18

DOI: https://doi.org/10.32792/utq/utjmed/19/1/6

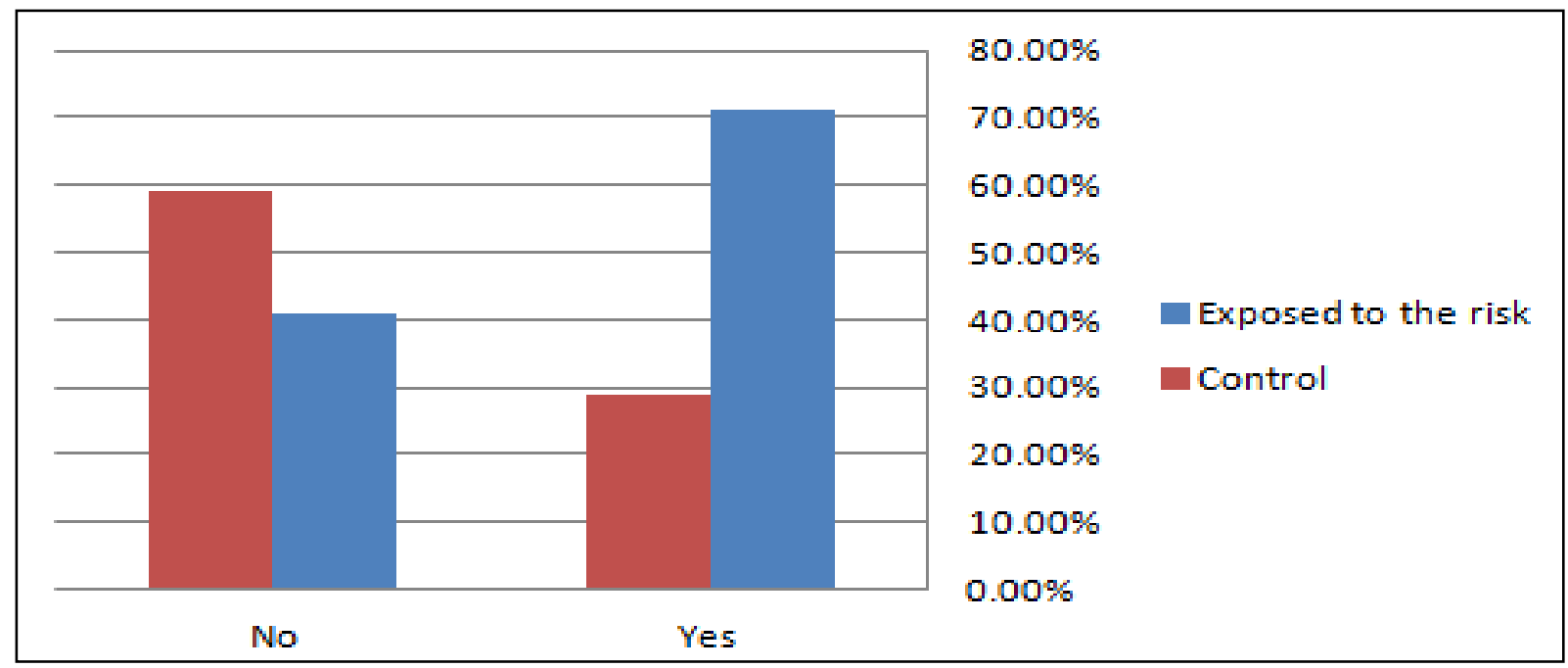

Figure 3:Percentage of visual disturbance among exposed to risk group(users of digital devices) and control group

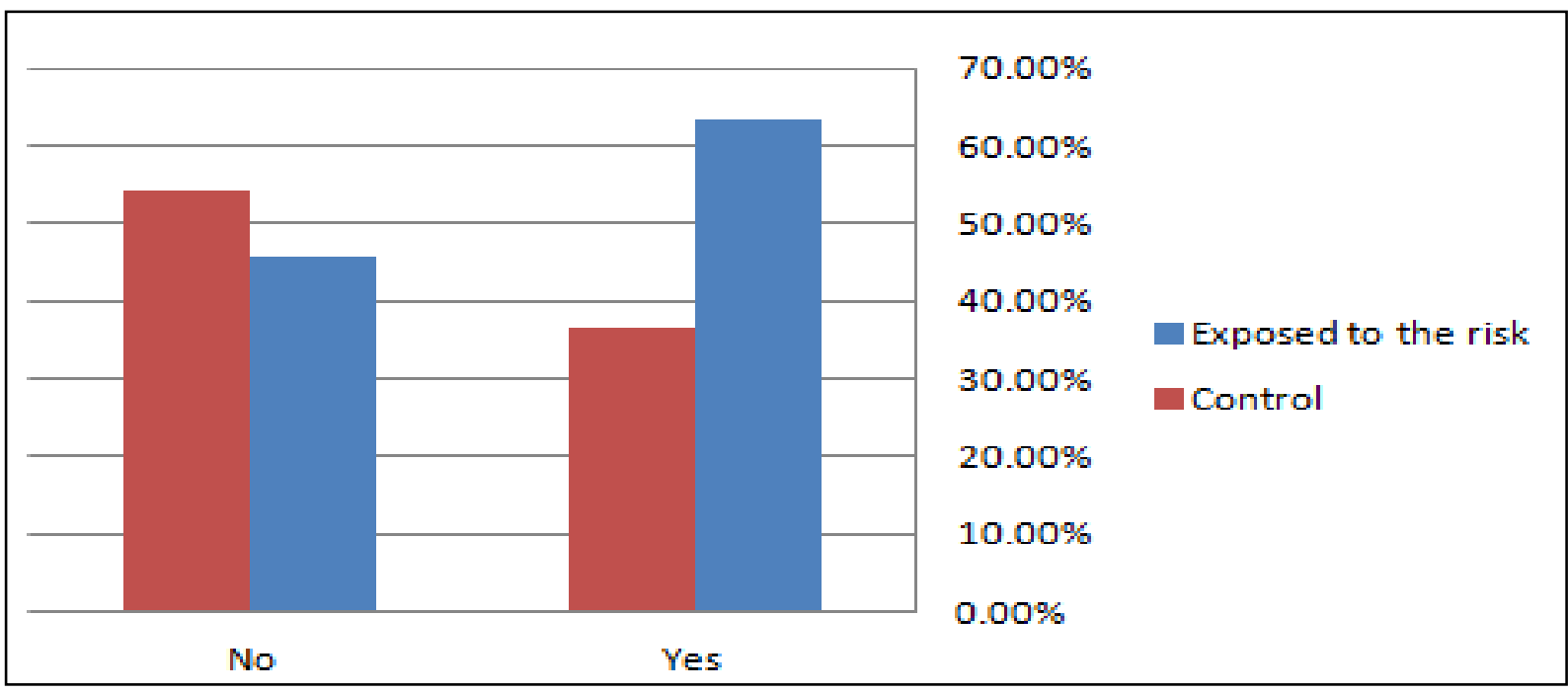

Figure 4:Percentage of headache among exposed to risk group(users of digital devices) and control group 
Web Site: https://jmed.utq.edu.iq

ISSN (Print):1992-92 18, ISSN (Online):1992-92 18

DOI: https://doi.org/10.32792/utq/utjmed/19/1/6

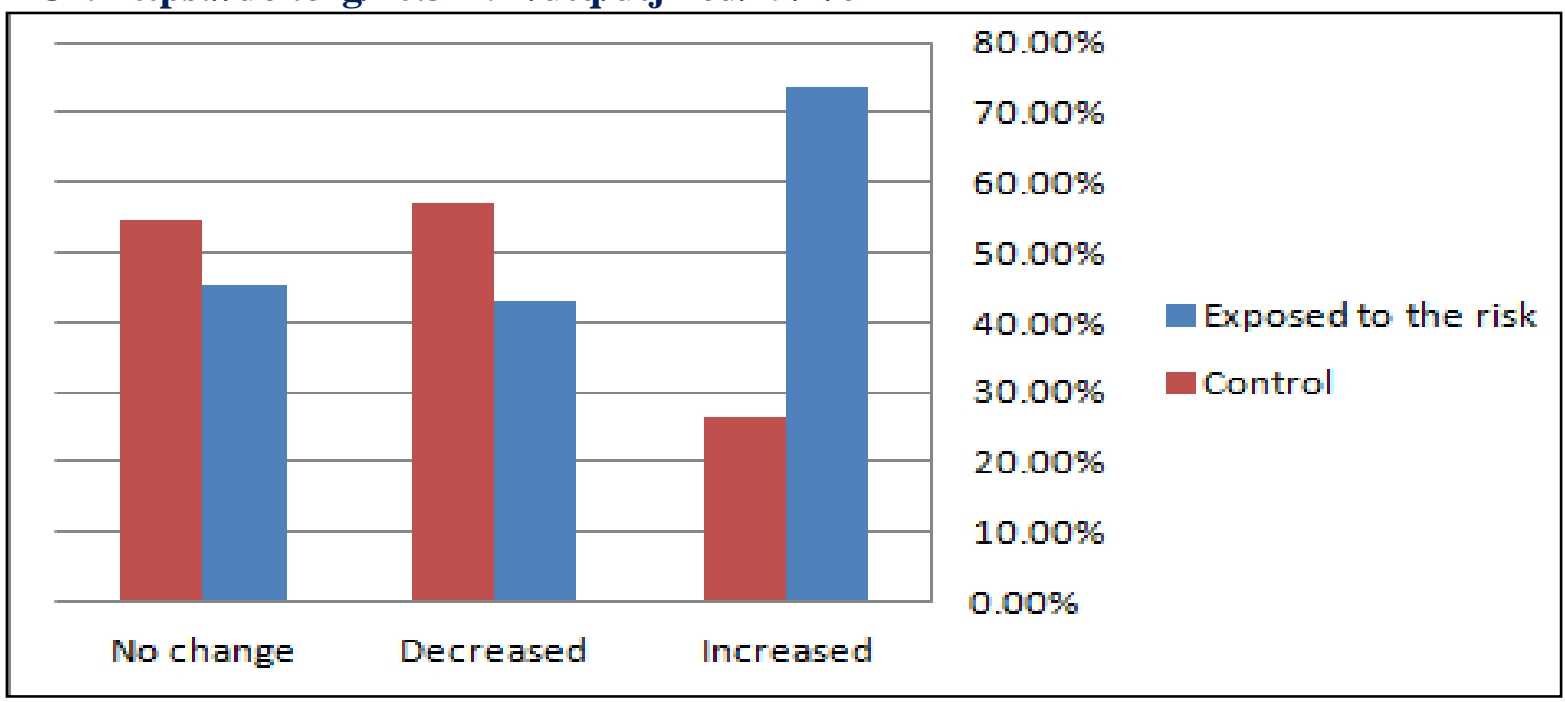

Figure 5:Percentage of changes in learning abilities among exposed to risk group(users of digital devices) and control group

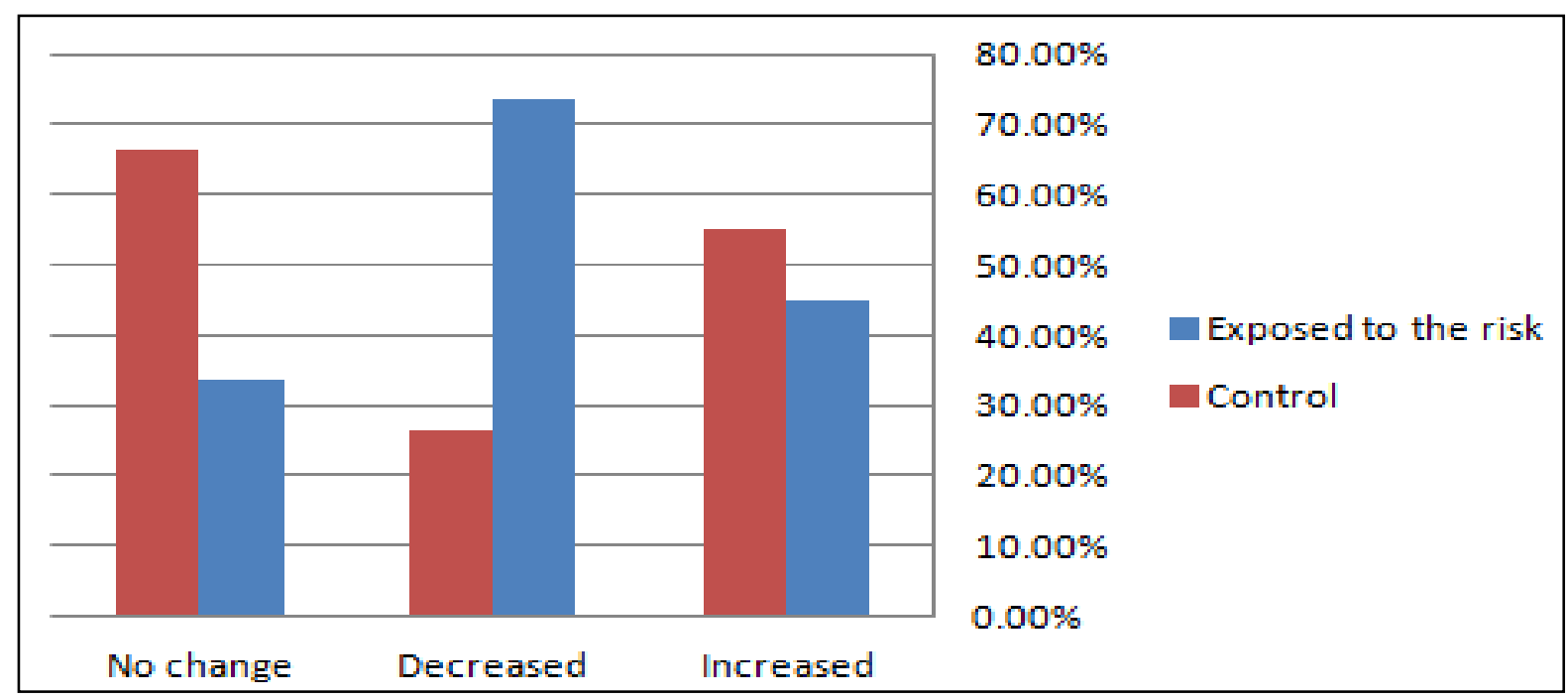

Figure 6:Percentage of changes in playing with the others (social communications) among exposed to risk group(users of digital devices) and control group 
ISSN (Print):1992-92 18, ISSN (Online):1992-92 18

DOI: https://doi.org/10.32792/utq/utjmed/19/1/6

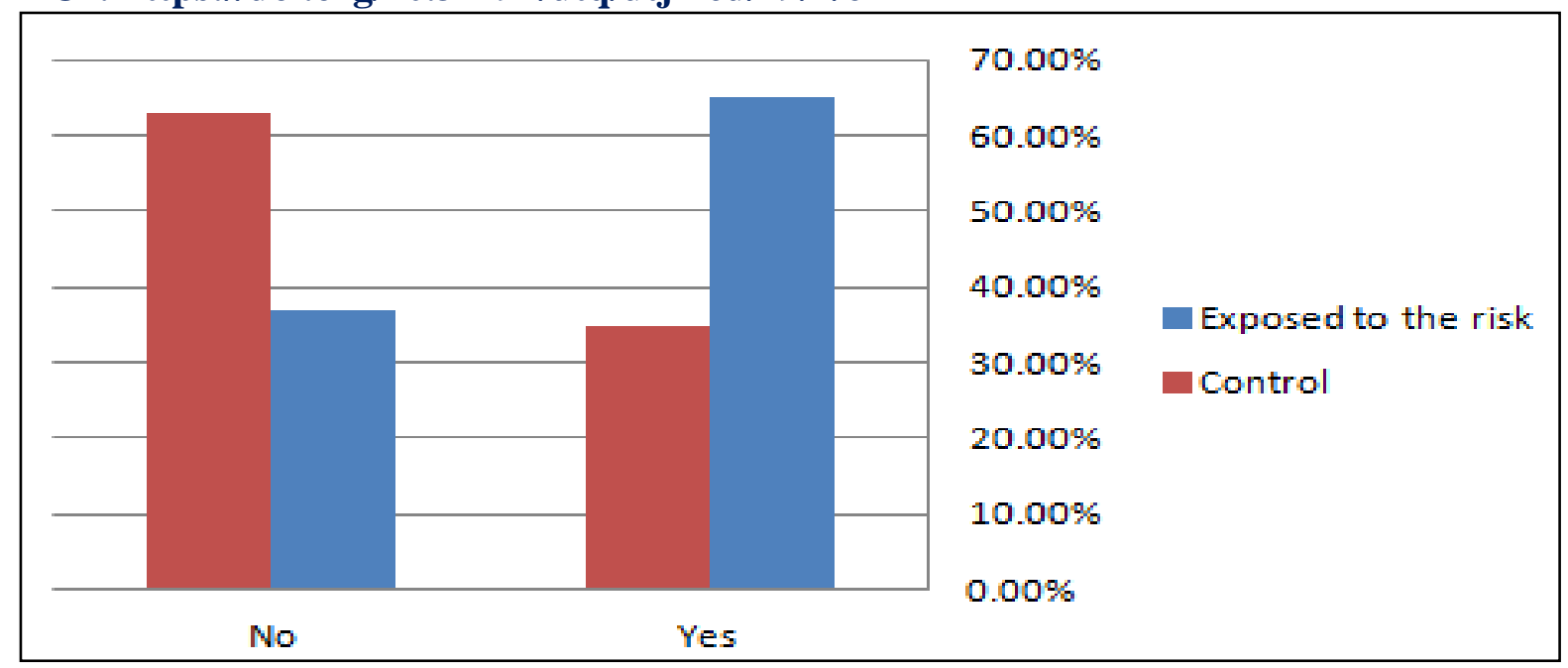

Figure 7:Percentage of changes in wakeup time and abilities among exposed to risk group(users of digital devices) and control group

These results are similar to those of many studies worldwide $(13,14,15,16)$, but the researchers in this study could not assessed the effects of smart devices on children body weight because most of the families living in society of Thi - Qar Governorate have no accurate measurement of body weight over prolong period.

\section{Conclusion :}

Prolong using of smart devices have many adverse effects on child health and behaviors in the form of aggressive behavior, decrease in school performance , headache, neck pain, visual problems and appetite disturbances, but its usage might increase their learning abilities .

\section{Recommendations :}

1- Encourage zero media usage for children under than 2 years of age.

2- Limit the time of usage in children over 10 years of age.
3- Inform the parents about the adverse effects of digital devices on their child health.

4- Encourage other forms of playing, especially in children younger than 5 years of age as playing with blocks, coloring on blank paper or sport activities

5- Do not put a television set or digital devices in the child bedroom .

6- $\quad$ Further studies are recommended to follow up the effect of digital devices on child health and behavior. 
Web Site: https://jmed.utq.edu.iq

ISSN (Print):1992-92 18, ISSN (Online):1992-92 18

DOI: https://doi.org/10.32792/utq/utjmed/19/1/6
Email:utjmed@utq.edu.iq

\section{References :}

1-B 1 a u, J o h n. "Mobile Te c h n ol o g y Ke e p s Tra ck of Ki ds. "PCWorld. PCWor 1 d C ommun i c ations In c, 31 De c 2003.

2- B r own, Te ri. "Vi d e o Game s Get Phy sic a 1. " Te e nagers Today. Dis ne y, n.d. We b. 12 Mar 2011

3- C amp be 11, Marily n. "The Imp a c t of the Mo bile P h o n e on Young P e o p 1 e's S o cial Life." ( 2005 ): 2 - 10 . We b. 15 Apr 2011.

4- Alvarenga KF, Amorim RB, Agostinho-Pesse RS, Costa OA, Nascimento LT, Bevilacqua MC. Int J PediatrOtorhinolaryngol. 2012 Sep;76(9):1332-8. doi: 10.1016/j.ijporl.2012.06.001. Epub 2012 Jul 15.

5- Breshears JD, Gaona CM, Roland JL, Sharma M, Anderson NR, Bundy DT, Freudenburg ZV, Smyth MD, Zempel J, Limbrick DD, Smart WD, Leuthardt EC.

Pediatrics. 2011 Jul;128(1):e160-8. doi: 10.1542/peds.2010-1519. Epub 2011 Jun 20.

6- Wu CS, Fowler C, Lam WY, Wong HT, Wong CH, Yuen Loke A.

Ital J Pediatr. 2014 May 7;40:44. doi: 10.1186/1824-7288-40-44.

7- Gros s, Do u g." S o c i a lnet works andkids: How y o ung is t o o y o ung? ." CNNTech. Cable News Net work, 02 Nov 2009 . We b. 15 F e b 2011 . < h t t p : // articles.cnn.com/2009-11-02/tech/kids.social.networks_1_so

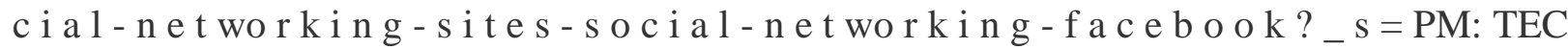
$\mathrm{H}>$.

8- Le ung, Linda." To p Ten Skills in Demandin 2010 . "GlobalKnowledg $e$. Gl o b a 1 Kn owl e d g e

Tr a i n in g LC C, n. d. We b. 12 Ma r 2011.

9- Hamp to n, Ke ith." S o c i al Is olation a nd New Te chnology. "Pew Inter $n$ e t. P ew In ternet a n d

Ame ri ca n Lif e Project, 4 Nov 2009 . We b. 15 Mar 2011.

10- He a 1 y, Melis s a." Teenages oc ial mediabutterflies may notbes uc ha b a dide a. "Los Angeles

Times. Lo s An ge le s Times, 18 Ma y 2010 . We b. 11 F e b 2011

11- Page AS, Cooper AR, Griew P, Jago R. Children's Screen Viewing is Related to Psychological Difficulties Irrespective of Physical Activity. Pediatrics. 2010;126:e1011-1017. doi: 10.1542/peds.2010-1154.

12- Dunstan DW, Barr EL, Healy GN, Salmon J, Shaw JE, Balkau B, Magliano DJ, Cameron AJ, Zimmet PZ, Owen N. Television viewing time and mortality: the Australian Diabetes, 
ISSN (Print):1992-92 18, ISSN (Online):1992-92 18

DOI: https://doi.org/10.32792/utq/utjmed/19/1/6

Obesity and Lifestyle Study (AusDiab) Circulation. 2010;121:384-391. doi: 10.1161/CIRCULATIONAHA.109.894824.

13- http://www.thevisioncouncil.org/consumers/media/VCDigital EyeStrainReport2012FINAL 14 -http://kidshealth.org/parent/positive/family/tv_affects_child.html

15- Garrison, M. M., Liekweg, K., Christakis, D. A. (2011). Media use and child sleep: the impact of content, timing, and environment. Journal of the American Academy of Pedatrics,

16- Garrison, M. M., Liekweg, K., Christakis, D. A. (2011). Media use and child sleep: the impact of content, timing, and environment. Journal of the American Academy of Pedatrics,

17- Council on Communications and Media (2011). Policy statement media use by children younger than 2 years . pediatrics , 128 ( 5) , $1-6$ 


\section{أثار استخدام الأجهزة الأكية على صحة وسلوك الطقل في محافظة ذي قار

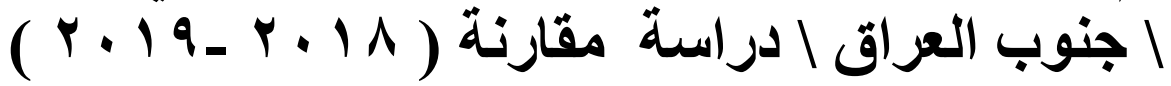 \\ فرع الأطفال/ كلية الطب/ جامعة ذي قار \\ فرع الأطفال/ كلية الطب/ جامعة ذي قار \\ مستثفى بنت الهدى للولادة والأطفال التعليمي / ذي قار/ العراق

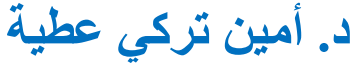

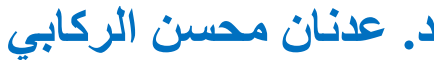

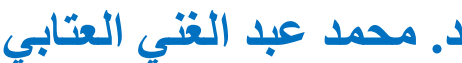

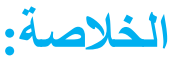

شهد العقد الماضي زيادة كبيرة في استخدام التكنلوجيا من قبل الاطفال، وبعظهم لا يتجاوز عمره سنة واحدة.

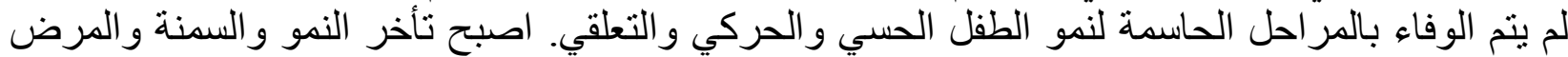
العقلي ونقص الانتباه و اضطر اب النمو وكذللك الاضطر ابات الاجتماعية مثل التو اصل و العدو النية وانية وانخفاض والترض التعاطف هي القاعدة. تهدف هذه الذّراسة الى تحديد فيما اذا كان هناللك أي ارتباط احصائي مهم بين الاستخدام الدفرط للأجهزة

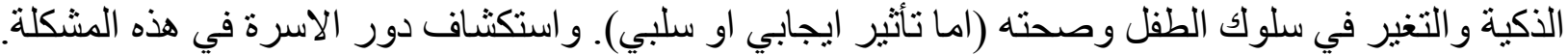

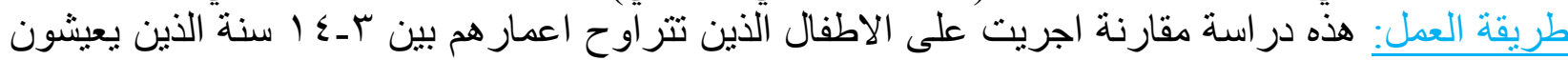

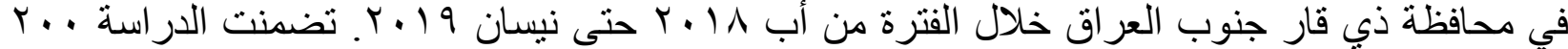

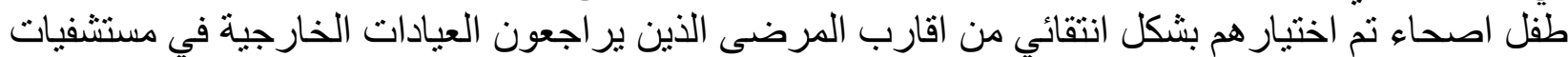

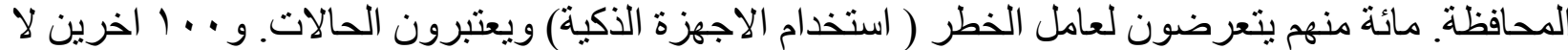

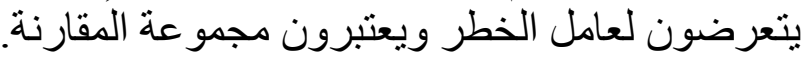

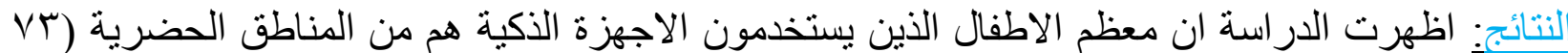

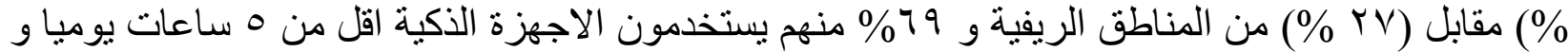

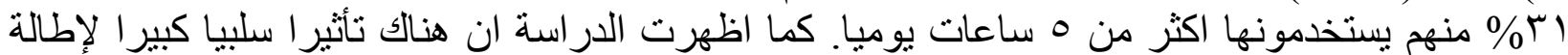

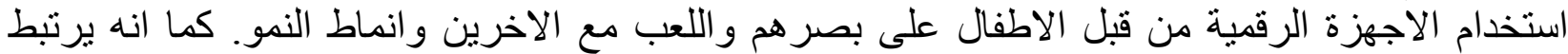

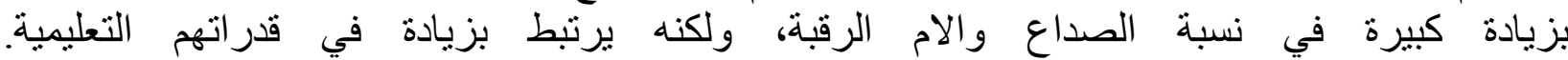

الاستنتاجات: أن استخدام الاجهزة الذكية لفترة طويلة له العديد من الآثار السلبية على صحة الطفل و سلوكه

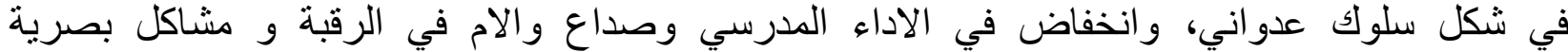

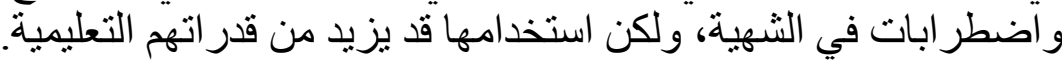

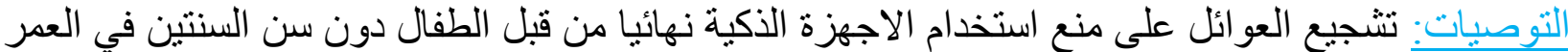

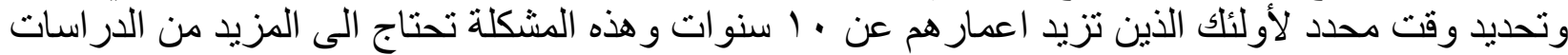
لمتابعة تأثير الاجهزة الرقمية على صحة و سلوك الطفل. 